\title{
25 Research Soure \\ Natural and Artificial Oxidation of Grape Seed Phenolics are Influenced by Extractability and Galloylation Pattern
}

Joshua VanderWeide

The University of British Columbia

Filippo Del Zozzo

Michigan State University

Esmaeil Nasrollahiazar

Michigan State University

James A. Kennedy

Function Phenolics LLC

Enrico Peterlunger

Università di Udine

\section{Laura Rustioni}

Università del Salento

Paolo Sabbatini ( $\sim$ sabbatin@msu.edu )

Michigan State University

\section{Research Article}

Keywords: polyphenol, tannin, oxidation, Pinot noir, Cabernet Sauvignon, ripening

Posted Date: November 18th, 2021

DOI: https://doi.org/10.21203/rs.3.rs-1027782/v1

License: (c) (7) This work is licensed under a Creative Commons Attribution 4.0 International License. Read Full License 


\section{Abstract}

In cool-climate viticulture, the short growing season can influence grape seed maturation by reducing the apparent oxidation of flavan-3-ols and associated increase in seed browning. A reduction in seed maturation increases the potential extraction of flavan-3-ols into wine during maceration operations, heightening bitterness. Here, we carried out a 2x2 factorial experiment to test the ability of freezing and heating treatments to artificially "ripen" seeds (decrease flavan-3-ols, improve browning) of (Vitis vinifera L.) Pinot noir and Cabernet Sauvignon over a 24-hour incubation period. Only freezing significantly increased seed browning in both cultivars. Subsequent correlations with seed flavan-3-ols concentrations suggest that freezing enhanced the oxidation of these compounds. Interestingly, natural ripening and freezing reduced galloylated flavan-3-ols to a greater extent than non-galloylated ones. This study provides new information regarding the susceptibility of flavan-3-ols to freezing and heating, and also suggests that freezing can artificially ripen the seeds of under-ripe red vinifera grapes.

\section{Highlights}

- Grape seed color and flavan-3-ol response to freezing and heating was tested.

- Heating and freezing browned seeds at veraison and harvest, respectively.

- Pinot noir and Cabernet Sauvignon seeds differed in non-galloylated flavan-3-ols.

- Natural ripening and freezing decreased extractability of galloylated flavan-3-ols.

- Seed browning and flavan-3-ol loss were correlated with seed water concentration.

\section{Introduction}

Fruit ripening in the grape berry is characterized by three growth stages; cell division (Stage I) and the expansion of cells and accumulation of solutes (veraison to harvest maturity) (Stage III) are separated by a lag phase in growth (Stage II). The maturation of grape seeds reflects this process. Seeds increase in fresh and dry weight during Stage I. This is also when seeds turn from green to yellow, and phenolics, mostly flavan-3-ols, accumulate in the outer integument cell layer (Ristic \& Iland, 2005). During the lag phase (Stage II), seeds reach their peak weight, and harden. Finally, the oxidative burst at veraison triggers a slow shift in seed color from green to yellow to dark brown in Stage III. The change in color has been associated with the oxidation of phenolic compounds that occurs between veraison and harvest (Kennedy et al., 2000). The seed color change is also accompanied by seed water loss and a reduction in seed weight (Kennedy et al., 2000; Pilati et al., 2007).

Seed phenolics are predominately comprised of flavan-3-ols (Mattivi, Vrhovsek, Masuero, \& Trainotti, 2009). The compounds particularly susceptible to oxidation are those having the ortho-dihydroxy substitution pattern, particularly those in large concentrations such as (+)-catechin, (-)-epicatechin, and epicatechin-3-0-gallate (Rustioni and Failla, 2016; Zheng et al., 2010). Oxidative polymerization leads to an apparent decrease in the mean degree of polymerization (mDP) of seed tannins during berry ripening (Kennedy et al., 2000), which decreases their extractability in wine (Del Rio \& Kennedy, 2006; Rousserie, Lacampagne, Vanbrabant, Rabot, \& Geny-Denis, 2020). 
The influence of grape seed tannins on wine has been investigated in studies that either add or remove grape seeds or seed-derived tannins to wine. The presence of seed tannins improved the color and pigmented polymer stability of Cabernet Sauvignon wines compared to tannins from skins or without tannin fractions from either seeds or skins (Bindon, et al, 2014). Likewise, seed removal in Monastrell wines decreased color intensity (Bautista-Ortín et al., 2014). Canals et al. (2008) revealed the positive relationship between seed presence and wine anthocyanin content, and also showed a correlation with wine astringency and bitterness. The total concentration of seed phenolics in wine was related to increased wine bitterness, but not astringency (Arnold \& Noble, 1978), however, more recent work showed that cultivars having a greater proportion of seed weight to berry weight produce more astringent wines (Gombau et al., 2020). Additionally, high concentrations of seed phenolics mask desirable wine aromas (Bautista-Ortín, Busse-Valverde, López-Roca, Gil-Muñoz, \& Gómez-Plaza, 2014; Cliff, Stanich, Edwards, \& Saucier, 2012; Parker et al., 2007). This may be why Sáenz-Navajas et al., (2015) revealed that the presence of astringency-related phenolics, including procyanidins, correlated negatively with consumer preference of red wine. Together, this information suggests that while phenolics are important to red wine color and organoleptic properties, excessive concentrations can compromise red wine flavour and quality.

In seasons having low growing degree day accumulation, cool climate-grown red vinifera cultivars can fail to reach harvest-quality maturity (VanderWeide, Tombesi, Castellarin, \& Sabbatini, 2020). This results in low sugar concentrations (low wine alcohol percent) and $\mathrm{pH}$ in the fruit, the latter of which exacerbates astringency perception in the final wine (Fontoin, Saucier, Teissedre, \& Glories, 2008). Additionally, seeds of underripe fruit contain higher and more extractable seed flavan-3-ol monomers, as well as procyanidin concentrations with a greater mDP (Bautista-Ortín et al., 2012; Brossaud, Cheynier, Asselin, \& Moutounet, 1999; Chira, Lorrain, Ky, \& Teissedre, 2011; Gombau et al., 2020), which can negatively impact wine quality due to increased astringency and bitterness (Del Llaudy, Canals, Canals, \& Zamora, 2008; Narukawa, Kimata, Noga, \& Watanabe, 2010; Vidal et al., 2003). In cool climate viticulture, grapevines are manipulated using cultural practices, such as cluster-zone leaf removal and cluster thinning, to advance ripening and improve harvest fruit quality (Diago, Ayestaran, Guadalupe, Poni, \& Tardaguila, 2012; Frioni et al., 2017; Gatti, Bernizzoni, Civardi, \& Poni, 2012; VanderWeide et al., 2018). However, these approaches have been shown to have little to no bearing on seed maturity (Kemp, Harrison, \& Creasy, 2011; Sivilotti et al., 2020; Talaverano et al., 2016), which presents a unique challenge for winemakers and suggests the need for a technique to alter bitter and astringent phenolic compounds in order to improve red wines made with underripe fruit.

One such enological approach is to remove seeds from red wine ferments after they sink to the bottom of fermentation tanks to limit extraction of seed phenolics (i.e.: early seed removal). Lee et al. (2008) reported a slight decrease in terminal galloylated flavan-3-ols in response to this approach, and a subsequent increase in $\mathrm{mDP}$, however, little difference in wine chemistry and quality were observed. Based on these results, it was hypothesized that phenolics from seeds are thoroughly extracted from seeds prior to settling (Lee et al., 2008; Meyer \& Hernandez, 1970). Likewise, other enological approaches to improve tannin quality in red wine have fallen short of addressing this issue (Harbertson, Parpinello, Heymann, \& Downey, 2012).

Our previous work reported that a "freeze-thaw" treatment artificially "ripened" seeds separated from berries by browning the seed coat of ten red Vitis vinifera L. cultivars (Rustioni et al., 2018). We hypothesized that this was due to enhanced oxidation of phenolic compounds and furthered this work with a second study. Here we observed that the change in seed color accompanied a significant alteration in phenolic compounds; ethanol extractable phenolics likely present in the vacuole were significantly reduced (VanderWeide et al., 2020). This 
work also suggested that these vacuolar phenolics may be decreasing due to covalent association with cell wall material (non-covalently bound phenolics), however, microscopy images revealed dark masses near cells with compromised structure; indicative that phenolic oxidation was also occurring (VanderWeide et al., 2020). In the current study, we expanded the experimental design and evaluated the seed extract phenolics to understand how concentrations of individual phenolic compounds respond to "freezing," "heating," (thawing temperature) and "incubation time" (thawing time). Our hypothesis was that, in addition to freezing, the higher thawing temperature and greater thawing time would enhance phenolic oxidation and the artificial ripening of both Pinot noir and Cabernet Sauvignon seeds.

\section{Materials And Methods}

\subsection{Experimental location and plant material}

Based on our previous studies evaluating the impact of a "freeze-thaw" treatment on seed color and phenolics change (Rustioni et al., 2018; VanderWeide et al., 2020), two Vitis vinifera L. cultivars were chosen for the experiment; Pinot noir (PN) and Cabernet Sauvignon (CS), which display high and low seed flavanol concentrations during maturation, respectively (Mattivi et al., 2009). PN and CS fruit used for the experiment were collected in a commercial vineyard located in Southwest Michigan, 12 Corners Vineyards and Winery, Benton Harbor, MI, 49022, United States (lat: 42.08 degrees, long: -86.22 degrees, Elevation: $227 \mathrm{~m}$ ) during the 2019 growing season. At veraison ( $11^{\circ} \mathrm{Brix}, 50 \%$ color change, 19 August) and harvest ( $20^{\circ} \mathrm{Brix}, 27$ September), 15 representative basal clusters were sampled for each cultivar, placed in plastic bags, and returned immediately to campus in coolers. Our experimental research and field studies on cultivated plants, complies with relevant institutional, national, and international guidelines and legislation.

\subsection{Experimental design and seed preparation}

The experiment was conducted according to a $2 \times 2$ factorial design (freezing, heating) with two cultivars (Pinot noir, Cabernet Sauvignon) and two sampling times (veraison, harvest). From the clusters collected at each sampling time, 1,200 berries were selected (for each cultivar) and distributed equally among 12 trays representing three replications of four treatments. The groups of 100 berries were manually adjusted to reach a similar weight and average berry color. Groups were then placed in separate Ziploc $\circledast$ bags and crushed. The seeds were separated from the pulp, rinsed with DI water, blotted dry with a KimWipe ${ }^{\circledR}$, and immediately evaluated for color analysis (2.4). Meanwhile, juice was stored for later analysis of basic fruit quality components (2.3). Each group of 100 berries was randomly assigned to one of four treatments, with each treatment having three replications. The first treatment $\left(T_{20} \mathrm{I}_{20}\right)$, considered as the control, consisted of seeds subjected to "no freezing" $\left(20^{\circ} \mathrm{C}\right)$ and incubation at $20^{\circ} \mathrm{C}$. The second treatment $\left(\mathrm{T}_{20} \mathrm{I}_{40}\right)$ was also not frozen $\left(20^{\circ} \mathrm{C}\right)$ but incubation at $40^{\circ} \mathrm{C}$. For the third treatment $\left(\mathrm{T}_{-20} \mathrm{O}_{20}\right)$, seeds were frozen at $-20^{\circ} \mathrm{C}\left(\mathrm{T}_{-20}\right)$ for 12 hours and then incubated at $20^{\circ} \mathrm{C}$. The fourth treatment $\left(\mathrm{T}_{-20} \mathrm{O}_{40}\right)$ included freezing seeds at $-20^{\circ} \mathrm{C}$ for 12 hours and incubation at $40^{\circ} \mathrm{C}$. Following seed removal and cleaning, seeds from each treatment were spread in a single layer across a $6 \mathrm{~cm}$ plastic weigh boat and incubated for $24 \mathrm{~h}$. For $\mathrm{I}_{40}$ treatments, weigh boats containing seeds were kept in a laboratory convection oven at $40^{\circ} \mathrm{C}$ and removed only for measurements during the time course study. For $\mathrm{T}_{-20}$ treatments, seeds in weight boats were placed in a $-20^{\circ} \mathrm{C}$ freezer over-night (12 hours) to ensure complete freezing of tissues. The following morning, weigh boats were removed from the freezer, and the time 
course study was initiated. The time course study consisted of taking seed colorimeter and chemical analysis samples at $0 \mathrm{~min}, 5 \mathrm{~min}, 1 \mathrm{~h}, 3 \mathrm{~h}, 6 \mathrm{~h}$, and $24 \mathrm{~h}$ during the incubation time. At each point, seeds were weighed, mixed within the weigh boat, subjected to color and chemical analysis, and quickly returned to the incubation experimental treatments.

\subsection{Basic fruit analysis}

Juice of PN and CS fruit previously placed in a $50 \mathrm{~mL}$ centrifuge tube was allowed to reach room temperature. Then, juice was centrifuged at $20^{\circ} \mathrm{C}$ for $5 \mathrm{~min}$ at $1000 \mathrm{xg}$ prior to analysis. Total soluble solids and total acidity (tartaric acid equivalents) were analysed with an ATAGO digital refractometer specific to grape (ATAGO, Tokyo, Japan) and pH was measured with a 370 Thermo Orion pH meter (Thermo Fisher Scientific, Inc., Waltham, MA).

\subsection{Color analysis}

Immediately after seed preparation, seeds were placed on a plastic weigh boat for incubation. Color measures occurred after $5 \mathrm{~min}, 1 \mathrm{~h}, 3 \mathrm{~h}, 6 \mathrm{~h}$ and $24 \mathrm{~h}$ during the incubation and after the freezing treatment. At each time point, a Konica Minolta Chroma Meter CR-400 (Konica Minolta, Osaka, Japan) was used to measure the seed color, and the weigh boat was not visible through the seeds. Afterward, seeds were mixed and re-settled into the weigh boat. This process was repeated an additional nine times, and the 10 measures were averaged. The three values generated from each measure ( $L$, lightness; $C$, chroma; $h$, hue) were combined into a single color index parameter using factor analysis according to VanderWeide et al. (2020).

\subsection{Phenolic extraction and analysis}

After the analysis of seed color at each time point, a subsample of 20 seeds from each treatment at different time points during the incubation time were placed in a $50 \mathrm{~mL}$ centrifuge containing $20 \mathrm{~mL}$ of extract solution ( $80 \% \mathrm{v} / \mathrm{v} \mathrm{MeOH}, 0.1 \% \mathrm{v} / \mathrm{v}$ formic acid) to extract seed phenolics. The covered tubes were wrapped with aluminum foil to prevent exposure to light and placed on a rotating platform at room temperature $\left(20^{\circ} \mathrm{C}\right)$ for 24 hours. After 24 hours, the extract solution was poured into another tube and stored at $-20^{\circ} \mathrm{C}$, while $15 \mathrm{~mL}$ of new extraction solution was added to the seeds and rotated for three hours. After this time, the extract solutions were combined and stored at $-20^{\circ} \mathrm{C}$. The extract solution was subjected to LC-MS using a Waters Acquity UHPLC interfaced to a Waters Xevo G2-XS Q-ToF mass spectrometer. Sample (10 $\mu \mathrm{L})$ was injected onto a Waters HSST3 UHPLC column $(2.1 \times 100 \mathrm{~mm}, 1.7 \mu \mathrm{m}$ particle size $)$ held at $40{ }^{\circ} \mathrm{C}$ using a binary gradient of water with $0.1 \%$ $\mathrm{v} / \mathrm{v}$ formic acid (solvent $\mathrm{A}$ ) and acetonitrile (solvent B). The solvent flow rate was $0.3 \mathrm{~mL} / \mathrm{min}$; it was started at time 0 with $100 \% \mathrm{~A}$, held for $0.5 \mathrm{~min}$ at $100 \% \mathrm{~A}$, ramped to $50 \% \mathrm{~B}$ at $6 \mathrm{~min}$, ramped to $99 \% \mathrm{~B}$ at $6.5 \mathrm{~min}$, held at $99 \%$ B until 8.5 min, reverted back to the starting condition of $100 \% \mathrm{~A}$ at $8.51 \mathrm{~min}$, and held until $10 \mathrm{~min}$. Compounds were ionized by electrospray ionization in negative-ion mode with a capillary voltage of $3.0 \mathrm{kV}$, a cone voltage at $35 \mathrm{~V}$, a source temperature of $100{ }^{\circ} \mathrm{C}$, and a desolvation temperature of $350{ }^{\circ} \mathrm{C}$. Data were acquired using a data-independent MSE method that consisted of two separate acquisition functions, one with no collision energy and the other with a collision-energy ramp of $20-80 \mathrm{~V}$. Compounds were annotated on the basis of their accurate masses, relative retention times, and fragmentation patterns. Peak areas were obtained using Quanlynx (part of the Waters Masslynx software). Standards of (+)-catechin and procyanidin B1 were used to quantify classes of flavan-3-ol monomers and procyanidins, respectively.

\subsection{Data elaboration and statistical analysis}


The color index (CI) was determined according to VanderWeide et al. (2020) and statistical analysis was conducted using SPSS statistical software (version PASW Statistics 24, SPSS, Inc. Chicago, IL). The heatmaps were generated using RStudio version 3.6.2 (Team, 2013) and data from treatments tested for significance from the control treatment using t-test $(p=0.05)$.

\section{Results And Discussion}

\section{A. Seed color is significantly browned by treatment conditions}

A color index $(\mathrm{Cl})$ was calculated to link all the three colorimeter parameters and better visualize the change in seed color during natural ripening and in response to treatments. Natural ripening led to significant seed browning (decrease in the index) in both PN and CS, however, the change in Cl was over 7-times greater in CS than PN (Table 1). This might be linked to higher concentrations of phenolic compounds in PN seeds compared

to other vinifera cultivars (Revilla, Alonso, \& Kovac, 1997). This result may also reflect the larger size of PN seeds compared to other vinifera cultivars, and therefore, a difference between PN and CS in the extractability of phenolic compounds and their susceptibility to oxidation (Mattivi et al., 2009). Finally, PN berries were slightly less ripe $\left(-1.5^{\circ}\right.$ Brix $)$ than CS despite harvesting fruit based on identical maturity in the field, which could influence the impact of natural ripening (Supplemental Table 1).

The incubation period impacted both cultivars significantly (Figure 1, Supplementary Figure 1). However, for each cultivar and sampling time, the point at which treatments changed from 'time 0 ' was different (Supplemental Figure 1). Seeds from all treatments in both cultivars browned significantly after $3 \mathrm{~h}$ at veraison. Meanwhile at harvest, seeds required $24 \mathrm{~h}$ and $6 \mathrm{~h}$ for PN and CS, respectively. For this reason, all three time points ( 3 h, 6 h, 24 h) were included in Table 1, which reveals a significant effect of the incubation time on seed color in both cultivars. Similar browning between cultivars during seed incubation (without the presence of pulp and skin tissues) suggests that the differences observed during natural ripening between PN and CS were attributed to physical components of the seeds.

In both PN and CS, freezing treatments induced an immediate browning of the seed color that lasted until $6 \mathrm{~h}$ (Figure 1, Supplemental Figure 1). While some effects were observed at veraison, freezing had a more significant impact on seeds at harvest. This confirms our previous work which reported a significant $\mathrm{Cl}$ change after $3 \mathrm{~h}$ post-freezing (Rustioni et al., 2018; VanderWeide et al., 2020). The cause for this greater effect on lignified seeds is intriguing, as lignification reduces the susceptibility of plant cells to freezing damage (Sano et al., 2016).

The effect of heating was impactful at veraison, with $\mathrm{T}_{20} \mathrm{I}_{40}$ having the darkest seeds in both cultivars after $24 \mathrm{~h}$ (Table 1, Figure 1). In contrast, harvest samples were unaffected by heating, contributing to the non-significant effect of heating on color when both timings are considered (Table 1). As seeds ripen, the inner-most cell layers of the outer integument lignify, making the seed less penetrable (Ristic \& Iland, 2005). This process diminishes the conductance of heat through these cell layers, as is important during seed dormancy (Sano et al., 2016).

\section{B. Natural ripening and artificial ripening oppositely influence the seed flavan-3-ol profile by the gallyolation pattern of compounds}

Among variables in this experiment, cultivar accounted for the largest variability in the seed extract flavan-3-ol profile (Figure 2). The majority of compounds influenced by cultivar were non-galloylated, while galloylated 
flavan-3-ols explained little variance (Figure 2, Figure 3A, B). This may be because non-galloylated flavan-3-ols, such as (+)-catechin and (-)-epicatechin, are represented in the highest concentrations in grape seeds and vary greatly between cultivars (Mattivi et al., 2009). Likewise, Núñez et al., (2006) reported that non-galloylated flavan-3-ols are negatively correlated with mDP (differ greatly by berry maturity). This suggests that the substantial oxidation and polymerization experienced by these compounds during fruit ripening may also influence their cultivar-dependent concentrations (Kennedy et al., 2000). Meanwhile, alterations in monogalloylated flavan-3-ols are thought to be more season-dependent (Núñez et al., 2006).

In contrast, natural ripening and freezing treatment induced a larger change to galloylated compounds compared to non-galloylated ones (Figure 3, Supplementary Tables 3,4). With respect to natural ripening, the compound with the greatest relative decrease was epicatechin-3-O-gallate, a result observed previously (FerrerGallego, García-Marino, Miguel Hernández-Hierro, Rivas-Gonzalo, \& Escribano-Bailón, 2010; Kennedy et al., 2000). Additionally, there was a less visible effect on non-galloylated compounds. This led to both having a significant impact on the ratio of galloylated to non-galloylated flavan-3-ols (Table 2). Galloylated flavan-3-ols are formed by a condensation reaction using gallic acid (Watrelot \& Norton, 2020). This structure provides three additional hydroxyl groups capable of donating electrons. Galloylated flavan-3-ols have a higher free radical quenching capacity (DPPH) compared to non-galloylated ones, such as catechin and epicatechin (Colon \& Nerín, 2016; Roy et al., 2010). However, the oxygen radical absorbance capacity (ORAC) assay revealed the opposite trend (Ishimoto et al., 2012; Roy et al., 2010). This difference in antioxidant results may lie in the enhanced ability of galloylated flavan-3-ols to penetrate lipid bilayers due to their more lipophilic nature (Karas, Ulrichová, \& Valentová, 2017; Narukawa et al., 2010). Our previous work showed that freezing disrupts cell membranes and walls (VanderWeide et al., 2020), suggesting that this may allow galloylated compounds to become exposed to oxygen. Additionally, flavan-3-ols with galloyl groups were less stable at neutral pH (Narukawa et al., 2010). More recently, Kim et al., (2020) revealed that phenolics with a pyrogallol group were highly oxidizable under a $\mathrm{pH}=10$. This suggests that seeds out of wine-like (low $\mathrm{pH})$ solution may promote oxidation of galloylated phenolics.

Heating treatment had an inconsistent effect on individual flavan-3-ol compounds. B-type and C-type procyanidins and total procyanidins were significantly increased and decreased in PN and CS, respectively. This led to no significant effect on the ratio of galloylated to non-galloylated flavan-3-ols extracted from seeds in either cultivar (Table 2).

\section{Relationships between seed color and flavan-3-ols composition.}

The Pearson's correlation coefficients between the seed color index and seed flavan-3-ol groups (galloylated, non-galloylated, and their ratio) are displayed in Table 3. When the data from both cultivars are considered together, all flavan-3-ol groups are correlated strongly with the color index $(\mathrm{Cl})$, reflective of the relationship between seed phenolic concentration and color (Rustioni \& Failla, 2016). However, when examined on a cultivardependent basis, these correlations were only completely upheld in CS (Table 3). In PN, the relationship between the $\mathrm{Cl}$ and total flavan-3-ols, galloylated flavan-3-ols, and the ratio of galloylated flavan-3-ols to non-galloylated compounds were significant. But there was no relationship between $\mathrm{Cl}$ and non-galloylated flavan-3-ols. This suggests that despite the large decrease in non-galloylated flavan-3-ols during natural ripening, that galloylated flavan-3-ols may play a large role in seed color determination in proportion to their concentration. Given the location of compounds largely comprising the non-galloylated fraction in vacuoles of cells, it may be that 
differences in extractability of compounds may be influencing this difference between cultivars (Mattivi et al., 2009). Future works will seek to establish whether the structural characteristics of seeds influence seed coloration during ripening and in response to artificial ripening treatments.

\section{Implications of artificial ripening on grape and wine quality}

Grape growers often utilize seed color and organoleptic properties as a basis for harvest maturity of fruits. This study reveals that seed color may not a be a sufficient marker alone to determine grape ripeness due to the large variability among cultivars in the concentration of compounds related to both of these parameters (Rustioni \& Failla, 2016). It is well established that galloylated flavan-3-ols are a source of astringency in red grapes wines (Ćurko et al., 2014; Gombau et al., 2020; Narukawa et al., 2010). Flavan-3-ol monomers are also well known to impact bitterness in wine (Sáenz-Navajas et al., 2015). The results from this study provide some implications for wine quality based on these facts. Wines made with seeds subjected to freezing treatment should be less bitter and astringent due to the significant decrease in galloylated phenolics, which are also understood to more strongly interact with bitter taste receptors due to their lipophilic nature (Narukawa et al., 2010). However, freezing may in turn promote oxidative polymerization of procyanidins; a process known to enhance wine astringency (Vidal et al., 2003). The degree of procyanidin polymerization and galloylation were not analyzed in this study but will be a focus of future works. Likewise, given the potential differences in treatment effectiveness in must or wine solution (Oszmianski, Romeyer, Sapis, \& Macheix, 1986), future works will consider this aspect to truly understand whether this technique could positively influence red wine quality.

\section{Conclusions}

This work characterized the response of seed phenolics to natural ripening and several treatments aimed at artificially ripening seeds of Pinot noir and Cabernet Sauvignon. Seeds were separated from fruits and subjected to a 24-hour time-course study following the subjugation of seeds to $2 \times 2$ factorial treatments of no freezing $\left(20^{\circ} \mathrm{C}\right)$ or freezing $\left(-20^{\circ} \mathrm{C}\right)$ prior to the time-course and no heating $\left(20^{\circ} \mathrm{C}\right)$ or heating $\left(40^{\circ} \mathrm{C}\right)$ during the time course. Cultivar had a large impact on the concentrations of non-galloylated phenolics, while natural ripening and freezing had a greater effect on galloylated phenolics than non-galloylated ones. Finally, heating induced negligible changes to compounds, but primarily non-galloylated ones. This study provides new information regarding the susceptibility of phenolic compounds to freezing and heating, and also suggests a novel approach to improve the quality of seed-derived tannins and phenolics in underripe red vinifera cultivars. Future works will evaluate the true potential of this technique through sensory and oenologically-driven approaches.

\section{Declarations}

\section{Acknowledgements}

This work was supported by AgBio-Research at Michigan State University (Project GREEEN). We appreciate the assistance of Glen Greiffendorf (12 Corners Vineyards, Benton Harbor, MI, USA) for fruit samples and of Matthew Williams for his help in laboratory assistance and data collection. We would like to acknowledge Tony Schilmiller and the MSU Mass Spectrometry and Metabolomics Core for their aid.

\section{Declaration of Competing Interest}


The authors declare that they have no known competing financial interests or personal relationships that could have appeared to influence the work reported in this paper.

\section{References}

1. Arnold, R. A., \& Noble, A. C. (1978). Bitterness and Astringency of Grape Seed Phenolics in a Model Wine Solution. American Journal of Enology and Viticulture, 29(3), 150-152. Retrieved from

http://www.ajevonline.org/content/29/3/150.abstract

2. Bautista-Ortín, A. B., Rodríguez-Rodríguez, P., Gil-Muñoz, R., Jiménez-Pascual, E., Busse-Valverde, N., Martínez-Cutillas, A., ... Gómez-Plaza, E. (2012). Influence of berry ripeness on concentration, qualitative composition and extractability of grape seed tannins. Australian Journal of Grape and Wine Research, 18(2), 123-130. https://doi.org/10.1111/j.1755-0238.2012.00178.x

3. Bautista-Ortín, Ana B., Busse-Valverde, N., López-Roca, J. M., Gil-Muñoz, R., \& Gómez-Plaza, E. (2014). Grape seed removal: Effect on phenolics, chromatic and organoleptic characteristics of red wine. International Journal of Food Science and Technology, 49(1), 34-41. https://doi.org/10.1111/ijfs.12270

4. Bindon, K., Kassara, S., Hayasaka, Y., Schulkin, A., \& Smith, P. (2014). Properties of wine polymeric pigments formed from anthocyanin and tannins differing in size distribution and subunit composition. Journal of Agricultural and Food Chemistry, 62(47), 11582-11593. https://doi.org/10.1021/jf503922h

5. Brossaud, F., Cheynier, V., Asselin, C., \& Moutounet, M. (1999). Flavonoid Compositional Differences of Grapes Among Site Test Plantings of Cabernet franc. American Journal of Enology and Viticulture, 50(3), 277-284.

6. Canals, R., del Carmen Llaudy, M., Canals, J. M., \& Zamora, F. (2008). Influence of the elimination and addition of seeds on the colour, phenolic composition and astringency of red wine. European Food Research and Technology, 226(5), 1183-1190. https://doi.org/10.1007/s00217-007-0650-8

7. Chira, K., Lorrain, B., Ky, I., \& Teissedre, P. L. (2011). Tannin composition of cabernet-sauvignon and merlot grapes from the bordeaux area for different vintages (2006 to 2009) and comparison to tannin profile of five 2009 vintage mediterranean grapes varieties. Molecules, 16(2), 1519-1532.

https://doi.org/10.3390/molecules16021519

8. Cliff, M. A., Stanich, K., Edwards, J. E., \& Saucier, C. T. (2012). Adding Grape Seed Extract to Wine Affects Astringency and Other Sensory Attributes. Journal of Food Quality, 35(4), 263-271. https://doi.org/10.1111/j.1745-4557.2012.00448.x

9. Colon, M., \& Nerín, C. (2016). Synergistic, antagonistic and additive interactions of green tea polyphenols. European Food Research and Technology, 242(2), 211-220. https://doi.org/10.1007/s00217-015-2532-9

10. Ćurko, N., Kovačević Ganić, K., Gracin, L., Đapić, M., Jourdes, M., \& Teissedre, P. L. (2014). Characterization of seed and skin polyphenolic extracts of two red grape cultivars grown in Croatia and their sensory perception in a wine model medium. Food Chemistry, 145, 15-22.

https://doi.org/10.1016/j.foodchem.2013.07.131

11. Del Llaudy, M. C., Canals, R., Canals, J. M., \& Zamora, F. (2008). Influence of ripening stage and maceration length on the contribution of grape skins, seeds and stems to phenolic composition and astringency in wine-simulated macerations. European Food Research and Technology, 226(3), 337-344.

https://doi.org/10.1007/s00217-006-0542-3

Page 9/16 
12. Del Rio, J. L. P., \& Kennedy, J. A. (2006). Development of proanthocyanidins in Vitis vinifera L. cv. Pinot noir grapes and extraction into wine. American Journal of Enology and Viticulture, 57(2), 125-132.

13. Diago, M. P., Ayestaran, B., Guadalupe, Z., Poni, S., \& Tardaguila, J. (2012). Impact of prebloom and fruit set basal leaf removal on the flavonol and anthocyanin composition of Tempranillo grapes. American Journal of Enology and Viticulture, 63(3), 367-376. https://doi.org/10.5344/ajev.2012.11116

14. Ferrer-Gallego, R., García-Marino, M., Miguel Hernández-Hierro, J., Rivas-Gonzalo, J. C., \& Teresa EscribanoBailón, M. (2010). Statistical correlation between flavanolic composition, colour and sensorial parameters in grape seed during ripening. Analytica Chimica Acta, 660(1-2), 22-28.

https://doi.org/10.1016/j.aca.2009.09.039

15. Fontoin, H., Saucier, C., Teissedre, P. L., \& Glories, Y. (2008). Effect of pH, ethanol and acidity on astringency and bitterness of grape seed tannin oligomers in model wine solution. Food Quality and Preference, 19(3), 286-291. https://doi.org/10.1016/j.foodqual.2007.08.004

16. Frioni, T., Zhuang, S., Palliotti, A., Sivilotti, P., Falchi, R., \& Sabbatini, P. (2017). Leaf Removal and Cluster Thinning Efficiencies Are Highly Modulated by Environmental Conditions in Cool Climate Viticulture. American Journal of Enology and Viticulture, 68(3), 325-335. https://doi.org/10.5344/ajev.2017.16098

17. Gatti, M., Bernizzoni, F., Civardi, S., \& Poni, S. (2012). Effects of Cluster Thinning and Preflowering Leaf Removal on Growth and Grape Composition in cv. Sangiovese. American Journal of Enology and Viticulture, 63(3), 325-332. https://doi.org/10.5344/ajev.2012.11118

18. Gombau, J., Pons-Mercadé, P., Conde, M., Asbiro, L., Pascual, O., Gómez-Alonso, S., ... Zamora, F. (2020). Influence of grape seeds on wine composition and astringency of Tempranillo, Garnacha, Merlot and Cabernet Sauvignon wines. Food Science \& Nutrition, (March), fsn3.1627. https://doi.org/10.1002/fsn3.1627

19. Harbertson, J. F., Parpinello, G. P., Heymann, H., \& Downey, M. O. (2012). Impact of exogenous tannin additions on wine chemistry and wine sensory character. Food Chemistry, 131(3), 999-1008. https://doi.org/10.1016/j.foodchem.2011.09.101

20. Ishimoto, H., Tai, A., Yoshimura, M., Amakura, Y., Yoshida, T., Hatano, T., \& Ito, H. (2012). Antioxidative Properties of Functional Polyphenols and Their Metabolites Assessed by an ORAC Assay. Bioscience, Biotechnology, and Biochemistry, 76(2), 395-399. https://doi.org/10.1271/bbb.110717

21. Karas, D., Ulrichová, J., \& Valentová, K. (2017). Galloylation of polyphenols alters their biological activity. Food and Chemical Toxicology, 105, 223-240. https://doi.org/10.1016/j.fct.2017.04.021

22. Kemp, B. S., Harrison, R., \& Creasy, G. L. (2011). Effect of mechanical leaf removal and its timing on flavan3-ol composition and concentrations in Vitis vinifera L. cv. Pinot Noir wine. Australian Journal of Grape and Wine Research, 17(2), 270-279. https://doi.org/10.1111/j.1755-0238.2011.00150.x

23. Kennedy, J. A., Troup, G. J., Pilbrow, J. R., Hutton, D. R., Hewitt, D., Hunter, C. R., ... Jones, G. P. (2000). Development of seed polyphenols in berries from Vitis vinifera L. cv. Shiraz. Australian Journal of Grape and Wine Research, 6, 244-254.

24. Kim, J., Pälijärvi, M., Karonen, M., \& Salminen, J.-P. (2020). Distribution of enzymatic and alkaline oxidative activities of phenolic compounds in plants. Phytochemistry, 179, 112501.

https://doi.org/10.1016/j.phytochem.2020.112501

Page $10 / 16$ 
25. Lee, J., Kennedy, J., Devlin, C., Redhead, M., \& Rennaker, C. (2008). Effect of early seed removal during fermentation on proanthocyanidin extraction in red wine: A commercial production example. Food Chemistry, 107(3), 1270-1273. https://doi.org/10.1016/j.foodchem.2007.08.041

26. Mattivi, F., Vrhovsek, U., Masuero, D., \& Trainotti, D. (2009). Differences in the amount and structure of extractable skin and seed tannins amongst red grape varieties. Australian Journal of Grape and Wine Research, 15(1), 27-35. https://doi.org/10.1111/j.1755-0238.2008.00027.x

27. Meyer, B. J., \& Hernandez, R. (1970). Seed Tannin Extraction in Cabernet Sauvignon. Am. J. Enol. Vitic., 21(4), 184-188.

28. Narukawa, M., Kimata, H., Noga, C., \& Watanabe, T. (2010). Taste characterisation of green tea catechins. International Journal of Food Science \& Technology, 45(8), 1579-1585. https://doi.org/10.1111/j.13652621.2010.02304.x

29. Núñez, V., Gómez-Cordovés, C., Bartolomé, B., Hong, Y.-J., \& Mitchell, A. E. (2006). Non-galloylated and galloylated proanthocyanidin oligomers in grape seeds fromVitus vinifera L. cv. Graciano, Tempranillo and Cabernet Sauvignon. Journal of the Science of Food and Agriculture, 86(6), 915-921. https://doi.org/10.1002/jsfa.2438

30. Oszmianski, J., Romeyer, F. M., Sapis, J.-C., \& Macheix, J. J. (1986). Grape Seed Phenolics: Extraction as Affected by Some Conditions Occurring During Wine Processing. American Journal of Enology and Viticulture, 37(1), 7-12.

31. Parker, M., Smith, P. A., Birse, M., Francis, I. L., Kwiatkowski, M. J., Lattey, K. A., ... Herderich, M. J. (2007). The effect of pre- and post-ferment additions of grape derived tannin on Shiraz wine sensory properties and phenolic composition. Australian Journal of Grape and Wine Research, 13(1), 30-37.

https://doi.org/10.1111/j.1755-0238.2007.tb00069.x

32. Pilati, S., Perazzolli, M., Malossini, A., Cestaro, A., Demattè, L., Fontana, P., ... Moser, C. (2007). Genome-wide transcriptional analysis of grapevine berry ripening reveals a set of genes similarly modulated during three seasons and the occurrence of an oxidative burst at vèraison. BMC Genomics, 8(1), 428. https://doi.org/10.1186/1471-2164-8-428

33. Revilla, E., Alonso, E., \& Kovac, V. (1997). The content of catechins and procyanidins in grapes and wines as affected by agroecological factors and technological practices. Wine: Nutritional and Therapeutic Benefits, 661, 69-80. https://doi.org/10.1021/bk-1997-0661

34. Ristic, R., \& Iland, P. G. (2005). Relationships between seed and berry development of Vitis Vinifera L. cV Shiraz: Developmental changes in seed morphology and phenolic composition. Australian Journal of Grape and Wine Research, 11(1), 43-58. https://doi.org/10.1111/j.1755-0238.2005.tb00278.x

35. Rousserie, P., Lacampagne, S., Vanbrabant, S., Rabot, A., \& Geny-Denis, L. (2020). Influence of berry ripeness on seed tannins extraction in wine. Food Chemistry, 315(July 2019), 126307.

https://doi.org/10.1016/j.foodchem.2020.126307

36. Roy, M. K., Koide, M., Rao, T. P., Okubo, T., Ogasawara, Y., \& Juneja, L. R. (2010). ORAC and DPPH assay comparison to assess antioxidant capacity of tea infusions: Relationship between total polyphenol and individual catechin content. International Journal of Food Sciences and Nutrition, 61(2), 109-124. https://doi.org/10.3109/09637480903292601

37. Rustioni, L., \& Failla, O. (2016). Grape Seed Ripening Evaluation By Ortho-Diphenol Quantification. Italian Journal of Food Science, 28, 510-516.

Page $11 / 16$ 
38. Rustioni, Laura, Cola, G., VanderWeide, J., Murad, P., Failla, O., \& Sabbatini, P. (2018). Utilization of a freezethaw treatment to enhance phenolic ripening and tannin oxidation of grape seeds in red ( Vitis vinifera $L$.) cultivars. Food Chemistry, 259(November 2017), 139-146.

https://doi.org/10.1016/j.foodchem.2018.03.120

39. Rustioni, Laura, \& Failla, O. (2016). Grape Seed Ripening Evaluation By Ortho -Diphenol Quantification. International Journal of Food Science \& Technology, 28, 510-516.

40. Sáenz-Navajas, M. P., Avizcuri, J. M., Ballester, J., Fernández-Zurbano, P., Ferreira, V., Peyron, D., \& Valentin, D. (2015). Sensory-active compounds influencing wine experts' and consumers' perception of red wine intrinsic quality. LWT - Food Science and Technology, 60(1), 400-411. https://doi.org/10.1016/j.Iwt.2014.09.026

41. Sano, N., Rajjou, L., North, H. M., Debeaujon, I., Marion-Poll, A., \& Seo, M. (2016). Staying Alive: Molecular Aspects of Seed Longevity. Plant and Cell Physiology, 57(4), 660-674. https://doi.org/10.1093/pcp/pcv186

42. Sivilotti, P., Falchi, R., VanderWeide, J., Sabbatini, P., Bubola, M., Vanzo, A., ... Herrera, J. C. (2020). Yield reduction through cluster or selective berry thinning similarly modulates anthocyanins and proanthocyanidins composition in Refosco dal peduncolo rosso (Vitis vinifera L.) grapes. Scientia Horticulturae, 264(August 2019), 109166. https://doi.org/10.1016/j.scienta.2019.109166

43. Talaverano, M. I., Moreno, D., Rodríguez-Pulido, F. J., Valdés, M. E., Gamero, E., Jara-Palacios, M. J., \& Heredia, F. J. (2016). Effect of early leaf removal on Vitis Vinifera L. cv. Tempranillo seeds during ripening based on chemical and image analysis. Scientia Horticulturae, 209, 148-155. https://doi.org/10.1016/j.scienta.2016.06.013

44. Team, R. C. (2013). R Core Team. https://doi.org/10.1108/eb003648

45. VanderWeide, J., Forte, A., Peterlunger, E., Sivilotti, P., Medina-Meza, I. G., Falchi, R., ... Sabbatini, P. (2020). Increase in seed tannin extractability and oxidation using a freeze-thaw treatment in cool-climate grown red (Vitis vinifera L.) cultivars. Food Chemistry, 308, 125571. https://doi.org/10.1016/j.foodchem.2019.125571

46. VanderWeide, J., Medina-Meza, I. G., Frioni, T., Sivilotti, P., Falchi, R., \& Sabbatini, P. (2018). Enhancement of Fruit Technological Maturity and Alteration of the Flavonoid Metabolomic Profile in Merlot ( Vitis vinifera L.) by Early Mechanical Leaf Removal. Journal of Agricultural and Food Chemistry, 66(37), 9839-9849. https://doi.org/10.1021/acs.jafc.8b02709

47. VanderWeide, J., Tombesi, S., Castellarin, S. D., \& Sabbatini, P. (2020). Canopy architecture and fruit microclimate, not ripening-related phytohormones, control phenylpropanoid accumulation in response to early leaf removal in 'Merlot' (Vitis vinifera L.) grapevines. Plant Physiology and Biochemistry, 157(July), 291-302. https://doi.org/10.1016/j.plaphy.2020.10.027

48. Vidal, S., Francis, L., Guyot, S., Marnet, N., Kwiatkowski, M., Gawel, R., ... Waters, E. J. (2003). The mouth-feel properties of grape and apple proanthocyanidins in a wine-like medium. Journal of the Science of Food and Agriculture, 83(6), 564-573. https://doi.org/10.1002/jsfa.1394

49. Watrelot, A. A., \& Norton, E. L. (2020). Chemistry and Reactivity of Tannins in Vitis spp.: A Review. Molecules, 25(9), 2110. https://doi.org/10.3390/molecules25092110

50. Zheng, C.-D., Li, G., Li, H.-Q., Xu, X.-J., Gao, J.-M., \& Zhang, A.-L. (2010). DPPH-Scavenging Activities and Structure-Activity Relationships of Phenolic Compounds. Natural Product Communications, 5(11), 17591765. 


\section{Tables}

Table 1. Impact of natural ripening, incubation time, freezing treatment, and heating treatment on the color index of Pinot noir and Cabernet Sauvignon seeds.

\section{Pinot noir}

\begin{tabular}{|c|c|c|c|c|c|c|c|c|c|c|}
\hline Parameter $^{1}$ & $A^{2}$ & vs. $B^{2}$ & A & B & $\begin{array}{l}\% \\
\text { change }\end{array}$ & $\begin{array}{l}p- \\
\text { value }\end{array}$ & A & B & $\begin{array}{l}\% \\
\text { change }\end{array}$ & $\begin{array}{l}p- \\
\text { value }\end{array}$ \\
\hline $\begin{array}{l}\text { Natural } \\
\text { ripening }\end{array}$ & Veraison & Harvest & 123 & 120 & $-2.44 \%$ & 0.022 & 123 & 99.5 & $-19.1 \%$ & $<0.001$ \\
\hline \multirow[t]{3}{*}{ Incubation } & $0 \mathrm{~min}$ & $3 \mathrm{~h}$ & 122 & 115 & $-5.74 \%$ & $<0.001$ & 110 & 103 & $-6.36 \%$ & 0.010 \\
\hline & $0 \mathrm{~min}$ & $6 \mathrm{~h}$ & 119 & 104 & $-12.6 \%$ & $<0.001$ & 112 & 103 & $-8.04 \%$ & 0.004 \\
\hline & $0 \mathrm{~min}$ & $24 \mathrm{~h}$ & 122 & 102 & $-16.4 \%$ & $<0.001$ & 110 & 100 & $-9.09 \%$ & $<0.001$ \\
\hline Freezing & $20^{\circ} \mathrm{C}$ & $-20^{\circ} \mathrm{C}$ & 114 & 105 & $-7.89 \%$ & $<0.001$ & 109 & 102 & $-6.42 \%$ & $<0.001$ \\
\hline Heating & $20^{\circ} \mathrm{C}$ & $40^{\circ} \mathrm{C}$ & 111 & 108 & $-2.70 \%$ & 0.069 & 105 & 105 & $0 \%$ & 0.986 \\
\hline
\end{tabular}

${ }^{1}$ Data from untreated seeds was used for analysis of natural ripening, while data from all treatments was used for analysis of other parameters.

${ }^{2} \mathrm{~A}$ and $\mathrm{B}$ describe the comparisons made between parameters in subsequent columns.

Table 2. Impact of natural ripening, freezing treatment, and heating treatment on the ratio of galloylated to nongalloylated flavan-3-ols in Pinot noir and Cabernet Sauvignon seed extracts.

Pinot noir

\begin{tabular}{llllllllllll}
\hline Parameter & A $^{2}$ & vs. & B $^{2}$ & A & B & $\begin{array}{l}\% \\
\text { change }\end{array}$ & $\begin{array}{l}\boldsymbol{p} \text { - } \\
\text { value }\end{array}$ & A & B & $\begin{array}{l}\% \\
\text { change }\end{array}$ & $\begin{array}{l}\boldsymbol{p} \text { - } \\
\text { value }\end{array}$ \\
\hline $\begin{array}{l}\text { Natural } \\
\text { ripening }\end{array}$ & Veraison & Harvest & 26.2 & 23.6 & $-9.92 \%$ & 0.002 & 43.9 & 16.5 & $-62.4 \%$ & $<0.001$ \\
\hline Freezing & $20^{\circ} \mathrm{C}$ & $-20^{\circ} \mathrm{C}$ & 24.9 & 19.7 & $-20.9 \%$ & $<0.001$ & 29.6 & 21.7 & $-26.7 \%$ & 0.011 \\
\hline Heating & $20^{\circ} \mathrm{C}$ & $40^{\circ} \mathrm{C}$ & 22.6 & 22.0 & $-2.65 \%$ & 0.504 & 26.2 & 25.0 & $-4.58 \%$ & 0.715
\end{tabular}

${ }^{1}$ Data from untreated seeds was used for analysis of natural ripening, while data from all treatments was used for analysis of other parameters.

${ }^{2} \mathrm{~A}$ and $\mathrm{B}$ describe the comparisons made between parameters in subsequent columns.

Table 3. Pearson correlations between the color index of Pinot noir and Cabernet Sauvignon seeds and the concentrations of flavan-3-ol groups in seed extracts. 


\begin{tabular}{|c|c|c|c|c|c|c|}
\hline Phenolic Group & $\begin{array}{l}\text { Both Cultivars } \\
\mathrm{R}^{2}\end{array}$ & $\begin{array}{l}p- \\
\text { value }\end{array}$ & $\begin{array}{l}\text { Pinot noir } \\
\mathrm{R}^{2}\end{array}$ & $\begin{array}{l}p- \\
\text { value }\end{array}$ & $\begin{array}{l}\text { Cabernet } \\
\text { Sauvignon } \mathrm{R}^{2}\end{array}$ & $\begin{array}{l}p- \\
\text { value }\end{array}$ \\
\hline Total $^{1}$ & 0.603 & $<0.001$ & 0.289 & 0.014 & 0.776 & $<0.001$ \\
\hline Galloylated & 0.663 & $<0.001$ & 0.417 & $<0.001$ & 0.792 & $<0.001$ \\
\hline Non-galloylated & 0.510 & $<0.001$ & 0.208 & 0.079 & 0.740 & $<0.001$ \\
\hline $\begin{array}{l}\text { Galloylated/ non- } \\
\text { galloylated }\end{array}$ & 0.560 & $<0.001$ & 0.368 & 0.001 & 0.755 & $<0.001$ \\
\hline
\end{tabular}

\section{Figures}

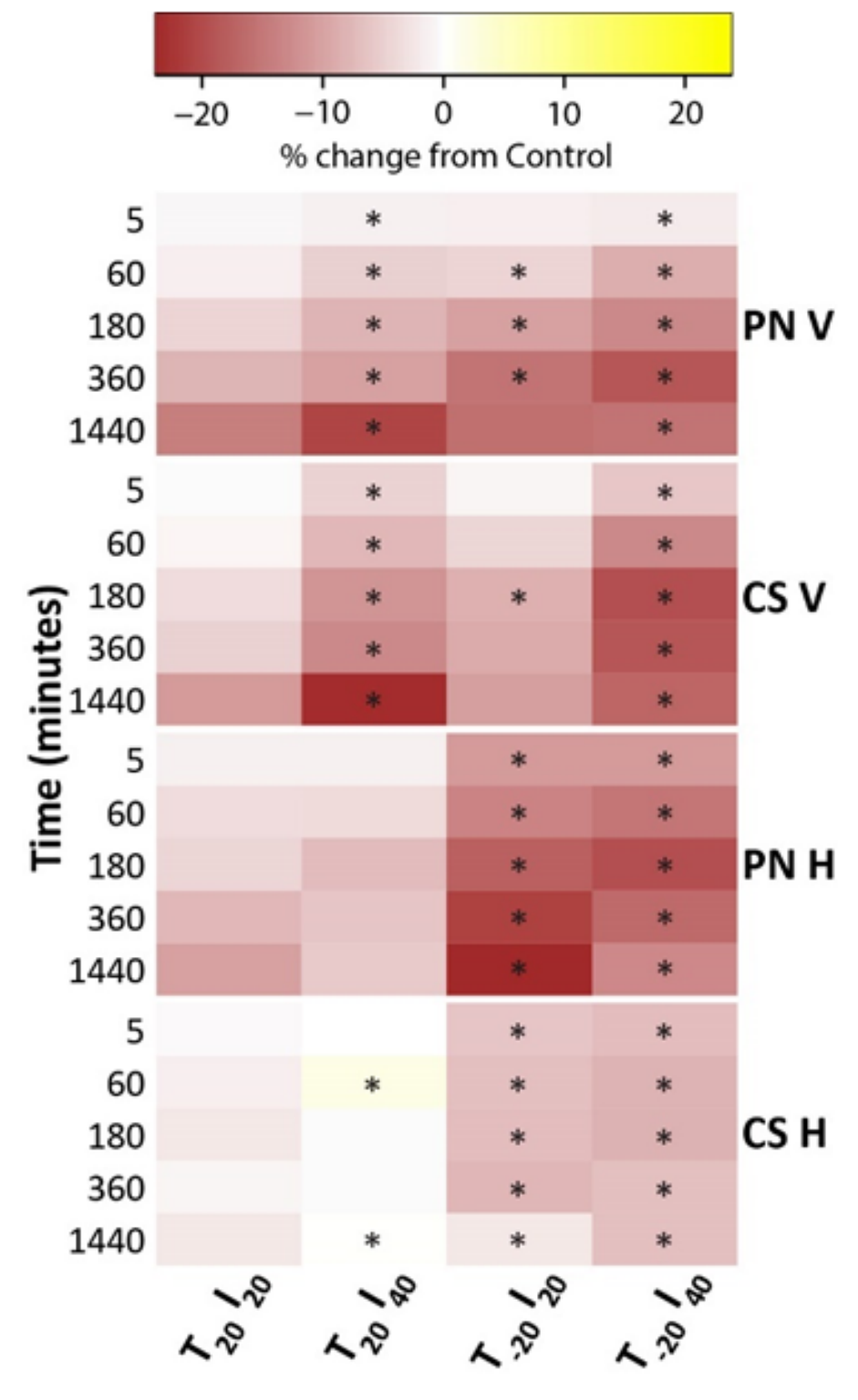

Figure 1 
Heatmap revealing the percent change of the seed color index over 24 hours in response to freezing and heating treatments. The treatment effect was analyzed by one-way ANOVA, and when the differences were significant, means were separated with Tukey's HSD test $(p<0.05)$. Treatments changed significantly from the control (T20I20) are marked with an asterisk. T20I20, no freezing and thawing at $20^{\circ} \mathrm{C} ; \mathrm{T} 20140$, no freezing and thawing at $40^{\circ} \mathrm{C}$; T-20I20, freezing at $-20^{\circ} \mathrm{C}$ and thawing at $20^{\circ} \mathrm{C} ; \mathrm{T}-20140$, freezing at $-20^{\circ} \mathrm{C}$ and thawing at $40^{\circ} \mathrm{C}$; time, sampling time; T, freezing temperature; I, incubation temperature. PN V, Pinot noir at veraison; CS V, Cabernet Sauvignon at veraison; $\mathrm{PN} \mathrm{H}$, Pinot noir at harvest; $\mathrm{CS} \mathrm{H}$, Cabernet Sauvignon at harvest.

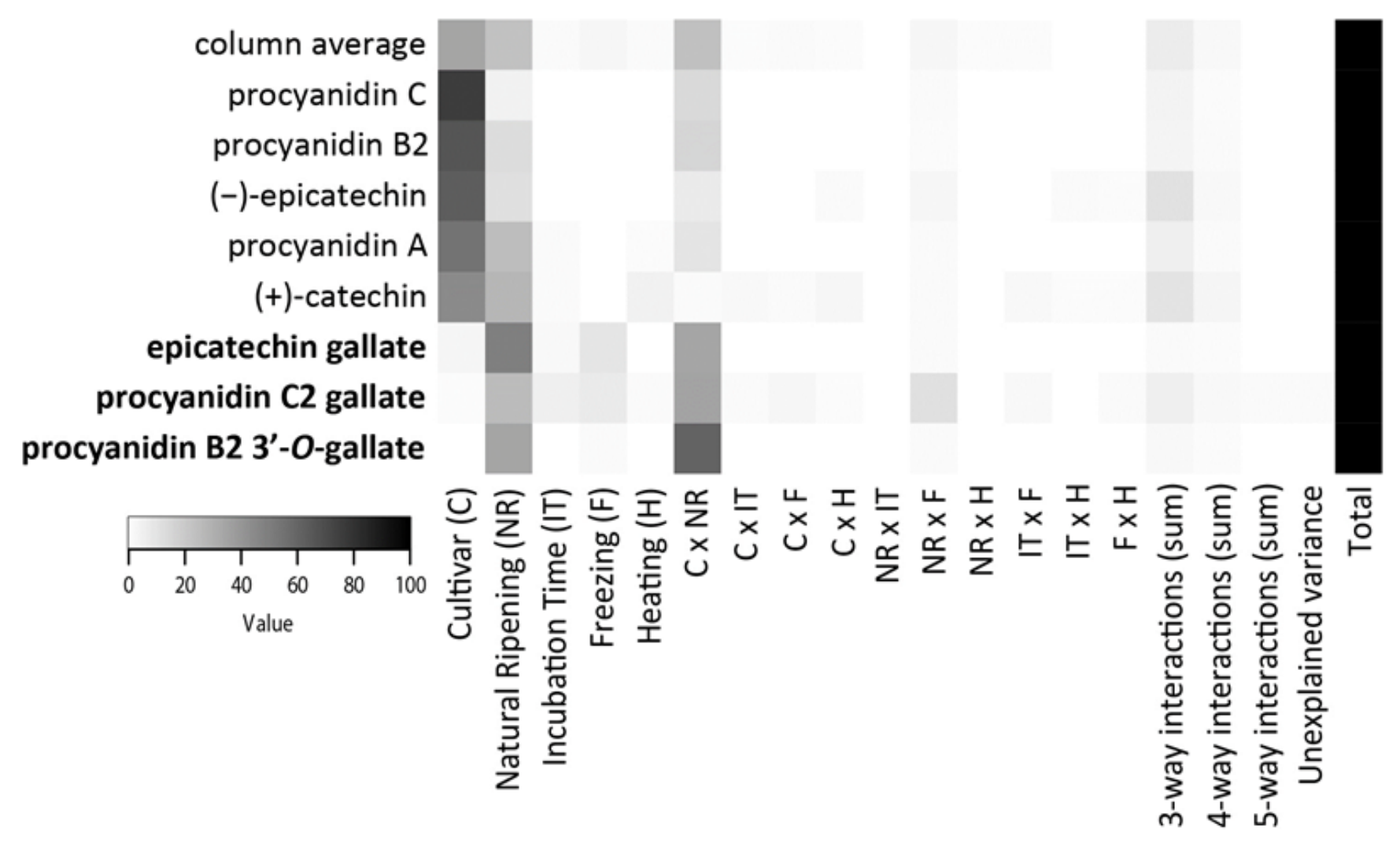

Figure 2

Heatmap displaying the variance in the seed flavan-3-ol profiles of Pinot noir and Cabernet Sauvignon seed extracts according to treatments and their interactions. 


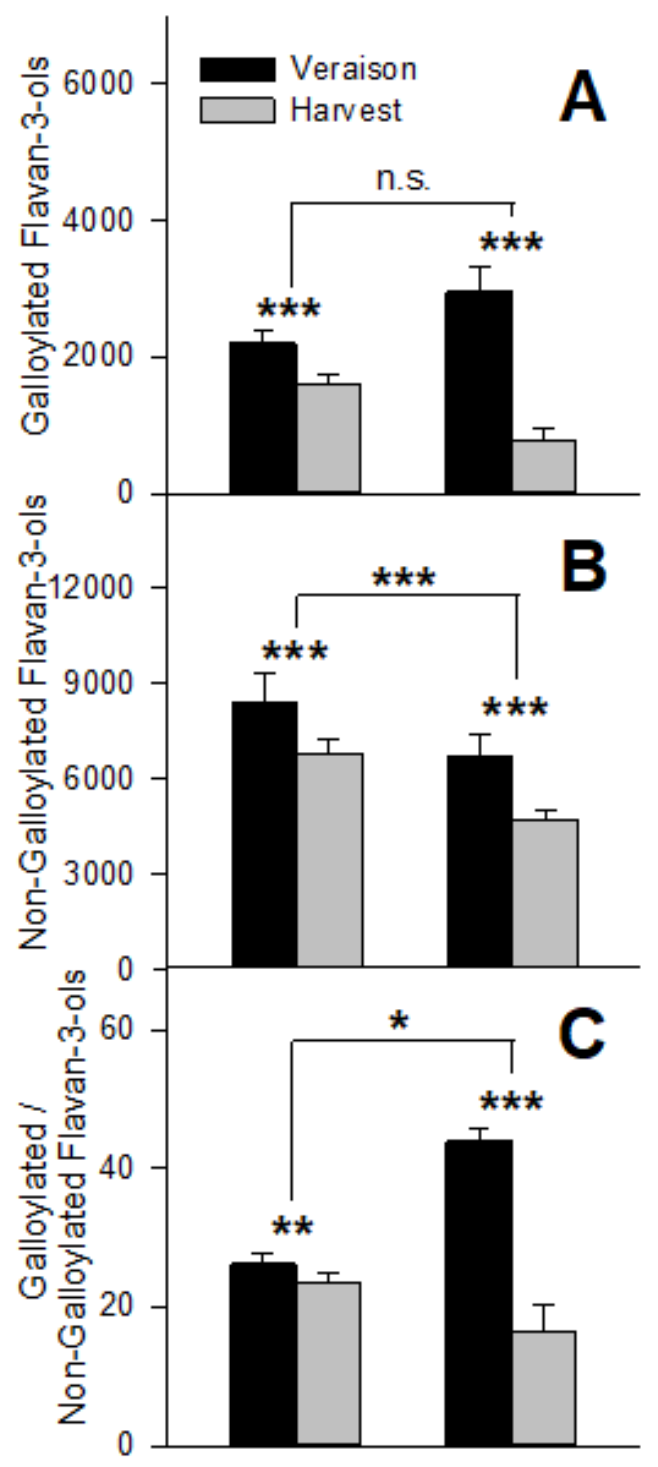

Figure 3

Influence of cultivar (Pinot noir, left; Cabernet Sauvignon, right) and natural ripening on the concentration ( $\mu \mathrm{g} / \mathrm{g}$ seeds FW) of A) galloylated flavan-3-ols, B) non-galloylated flavan-3-ols, and C) the ratio between galloylated and non-galloylated flavan-3-ols in seed extracts. Data from untreated seeds was used for analysis. Data is expressed as mean standard \pm deviation.

\section{Supplementary Files}

This is a list of supplementary files associated with this preprint. Click to download.

- SupplementalData.doc 